\title{
The Aftermath of Baker v. Carr-An Adventure in Judicial Experimentation
}

James B. Atleson*

[I]n a democratic country nothing is worse than disfranchisement. And there is no such thing as being just a little disfranchised. A free man's right to vote is a full right to vote or it is no right to vote. ${ }^{1}$

WT ITHIN seven weeks after the decision in Baker v. Carr $^{2}$ lawsuits were underway in twenty-two states. ${ }^{3}$ The assault on malapportioned legislatures had just begun.

Baker dramatically focuses attention on one of the oldest problems of representative government-malapportionment. The Court, however, failed to advance judicial standards by which courts could review legislative schemes. The task of selecting criteria to judge the constitutionality of legislative arrangements has been passed on to the lower courts. ${ }^{4}$

Thus far, courts have embarked upon the adventure with vigor and enthusiasm. The post-Baker cases present a "tremendous variance in statistics and legal reasoning" which "makes identification of a coherent doctrine or numerical standard next to impossible." 5 Nevertheless, the recent cases, and to some extent Baker itself, offer some insight into the problem of standards. The search for applicable standards requires a careful analysis of the interests involved in these cases. This article will outhine the

*A.B., Ohio State University, 1960; J.D., Ohio State University School of Law, I962; Teaching Fellow, Stanford University School of Law, 1962-64.

1 Gomillion v. Lightfoot, 270 F.2d 594, 612 (5th Cir. 1959) (Wisdom, J., concurring), rev'd 364 U.S. 339 (1960).

2369 U.S. 186 (1962).

3 N.Y. Times, May 14, 1962, p.1, col.2. For a summary of reapportionment hitigation begun during 1962, see McKay, Political Thickets and Crazy Quilts: Reapportionment and Equal Protection, 61 MTcH. L. Rev. 645, 706-10 (1963).

4 Hopefully, the Supreme Court will shed light on this problem in its next term. Probable jurisdiction has been noted for apportionment cases fron five states. Probable jurisdiction was noted in 31 U.S.L. WeEx 3404 (U.S. June 11, 1963) for the following cases: Mann v. Davis, 213 F. Supp. 577 (E.D. Va. 1962) (No. 797); Wright v. Rockefeller, 211 F. Supp. 460 (S.D.N.Y. 1962) (No. 950) ; W.M.C.A., Inc. v Simon, 208 F. Supp. 368 (S.D.N.Y. 1962) (No. 460) ; Wesberry v. Vandiver, 206 F. Supp. 276 (N.D. Ga. 1962) (No. 507); Maryland Comin. for Fair Representation v. Tawes, 229 Md. 445, 184 A.2d 710 (1962) (No. 554); Sims v. Frink, Civil No. 1744-N (M.D, Ala. decree filed July 25, 1962) (No. 610) ; Sims v. Frimk, 208 F. Supp. 431 (M.D. Ala. 1962) (Nos. 508, 540).

5 Goldberg, The Statistics of Malapportionment, 72 Yate L.J. 90, 97 (1962). 
various standards used in the post-Baker cases, and will attempt to analyze the interests at stake and the various justifications for malapportionment advanced by the states.

A search for applicable standards should begin with Baker itself. The general standard considered was the rationality of the state's policy. "[I]t has been open to courts since the enactment of the Fourteenth Amendment to determine ... that a discrimination reflects no policy, but simply arbitrary and capricious action." There must be some "rational policy behind the State's system." Mathematical exactness, however, is not required and there is room for weighting. "The prohibition of the Equal Protection Clause goes no further than ... invidious discrimination."8

As an original proposition, the failure to maintain equitably apportioned districts would seem to be a classic denial of equal protection. Under the most literal interpretation of equal protection a state may not apply its own law unequally. The situation is similar to a case in which state law is administered on a discriminatory basis. ${ }^{.}$Thus, plaintiff's counsel in Baker originally sought to use Tennessee's constitutional provisions as the basis for their equal protection claim. It was argued that if the state constitution requires equality in voting rights, then the denial of such equality by state officers is a denial of equal protection. ${ }^{10}$ The fourteenth amendment would require only that state laws be administered fairly.

The Court, however, based its decision on a federal standard, stating that the decision did not rest on the Tennessee constitution. It was deemed unnecessary to "consider, let alone enforce, rights under a State Constitution which go further than the protection of the Fourteenth Amendment."11 The implication is that the requirements of the fourteenth amendment are narrower than the equality prescribed by the Tennessee constitution. Indeed, some courts have refrained from imposing more than a minimal standard of equality even though the state law required a more rigorous standard. ${ }^{12}$

A meaningful line could have been drawn between "de jure" apportionment schemes (i.e., where, as in Baker, the legislature has refused to reapportion despite a state constitutional directive or where the legislature has acted in derogation of a state standard) and "de facto" schemes (i.e., where the state constitution itself creates, or does not prohibit malappor-

6369 U.S. at 226.

7 Id. at 253 (Clark, J., concurring).

$8 \mathrm{Id}$. at 245 (Douglas, $\mathrm{J}$., concurring).

${ }^{9}$ E.g., Yick Wo v. Hopkins, 118 U.S. 356 (1886).

10 Neal, Baker v. Carr: Politics in Search of Law, 1962 Supreme Court Rev. 252, 291-300

(Kurland ed.); see also Snowden v. Hughes, 321 U.S. 1 (1944).

11369 U.S. at 195 n.15.

12 See, e.g., Baker v. Carr, 206 F. Supp. 341 (M.D. Tenn. 1962). 
tionment). The remand in W.M.C.A., Inc. v. Simon ${ }^{13}$ and Scholle v. Hare, ${ }^{14}$ both de jure situations, and the Court's treatment of Baker indicate, however, that both situations will be treated alike for fourteenth amendment purposes.

It has been argued that apportionment cases do not fit the traditional equal protection mold because an individual concern with equality is not involved; ${ }^{15}$ a group is injured by not receiving proper representation in legislative halls and thus is deprived of power in the decision-making process. Although relief must be extended to a group, this does not mean the plaintiff has not suffered an individual injury. A judicial remedy that involves restructuring a legislative scheme may be the only way that a plaintiff's individual interests can be protected.

The extent to which there is any right to equal representation depends upon the state's freedom to develop schemes that depart from equality. The quantum of this freedom seems to depend upon the latitude accorded the states by the guarantee clause. ${ }^{10}$ Because the inquiry leads beyond equal protection, some courts have been compelled to discuss the problem in terms of a republican form of government. ${ }^{17}$ Indeed, whether or not numerical equality is a fundamental value revolves around an interpretation of the guarantee clause.

The extent to which the Supreme Court will review claims based on the guarantee clause has never been clearly enunciated. ${ }^{18}$ In Luther v. Borden ${ }^{19}$ a claim based upon the clause, which would have required the Court to decide which of two governments in Rhode Island was legitimate, was held nonjusticiable. In Pacific States Tel. \& Tel. Co. v. Oregon ${ }^{20}$ the clause was unsuccessfully invoked to challenge Oregon's initiative and referendum law as being inconsistent with a republican form of government. The Court again held the issue nonjusticiable. Justice Brennan, writing for the majority in Baker, apparently confirmed the view that all claims presented under the guarantee clause were nonjusticiable. ${ }^{21}$

13202 F. Supp. 741 (S.D.N.Y.), vacated and remanded, 370 U.S. 190 (1962).

14360 Mich. 1, 104 N.W.2d 63 (1960), vacated and remanded, 369 U.S. 429 (1962).

15 Neal, supra note 10, at 272-74.

16 Bonfield, Baker v. Carr: New Light on the Constitutional Guarantee of Republican Government, 50 CaIIF. L. REv. 245 (1962); Israel, The Future of Baker v. Carr, 61 MicH. L. REv. 107, 135 (1962).

17 See Toombs v. Fortson, 205 F. Supp. 248, 256 (N.D. Ga. 1962).

18 See Bonfield, The Guarantee Clause of Article IV, Section 4: A Study in Constitutional Desuetude, 46 MinN. L. Rev. 513 (1962).

1948 U.S. (7 How.) 1 (1849).

20223 U.S. 118 (1912).

21369 U.S. at 218. Justice Brennan's analysis, however, implies that a guarantee clause claim may be justiciable where no element of the "political question" doctrine is involved. For a thoughtful elaboration of this argument, see Bonficld, supra note 16. 
Although malapportionment cases involve assessment of the permissible schemes of representation in a republican state, ${ }^{22}$ it may not be entirely correct to say that the voters' claim is a "Guaranty Clause claim masquarading under a different label." ${ }^{\prime 23}$ Considerations of political structure may arise in apportionment cases, as Justice Frankfurter pointed out. This fact alone, however, should not prevent further analysis when the inquiry begins with equal protection. Representation is hardly more a part of a state's political structure than discriminatory practices in juror selection and voter qualification. ${ }^{24}$ If the Court considers the propriety of non-population factors in determining the validity of apportionment schemes, the republican form clause might be a more precise instrument than the equal protection clause. The Baker decision, however, casts the problem in an equal protection mold.

Traditionally, the equal protection analysis separates the purposes of the particular statute and the remoteness of the classification scheme to those purposes, and demands that any disparities be fairly related to the object of the statute. Two sets of judicial criteria mark the modern boundaries of equal protection. ${ }^{25}$

In cases involving economic or social regulations, the Court, since 1937, has deferred to legislative choices. ${ }^{26} \mathrm{It}$ has been unwilling to decide questions of desirability or to act as a "super-legislature." Acts have been sustamed as non-invidious if any state of facts could reasonably be conceived to justify the regulation. ${ }^{27}$ Under this very limited standard of rationality, most state apportionment schemes could pass muster. It seems apparent, however, that this approach is inappropriate for apportionment cases. ${ }^{28}$

Perhaps the closest parallel would be to the second class of equal protection cases, i.e., those involving individual rights and racial discrimination. There the impact upon the individual is carefully gauged, and the clause has been used to impose a "substantial burden of justification on the

22 Bonfield, supra note 16 at 256.

23 Baker v. Carr, 369 U.S. 186, 297 (1962) (Frankfurter, J., dissenting).

24 Id. at 222-23 n.48.

25 Friedelbaum, Baker v. Carr: The New Doctrine of Judicial Intervention and its Implications for American Federalism, 29 U. CEI. L. REv. 673 (1962).

${ }^{26}$ See, e.g., Williamson v. Lee Optical Co., 348 U.S. 483 (1955) (sustaining Oklahoma statute regulating persons involved with optical care); but see Morey v. Doud, 354 U.S. 457 (1957) (striking down state licensing of currency exchange).

27 Allied Stores of Ohio Inc. v. Bowers, 358 U.S. 522 (1959). Sunday closing laws have been upleld, even though some inequality resulted, because the classification rested on grounds not wholly irrelevant to the achievement of the state's objectives. McGowan v. Maryland, 366 U.S. 420 (1961); see also Tigner v. Texas, 310 U.S. 141 (1940).

28 "[T] $]$ here exists no standard ascertainable by settled judicial experience or process by reference to which a political decision affecting the question at issue between the partics can be judged." Baker v. Carr, supra note 23, at 282 (Frankfurter, J., dissenting). 
state." ${ }^{29}$ The claim in apportionment cases is that effective exercise of the franchise has been impaired by an "invidiously discriminatory geographic classification." ${ }^{\prime 30}$ As in the race cases, the object of the statute usually must be attacked, since the classification is usually related to the object. The inquiry in apportionment cases is whether the state can include non-population factors in devising its scheme. Those "similarly situated" must be similarly treated, but the problem arises in determining just who are similarly situated.

The choice between the two approaches used in equal protection cases will have a crucial effect upon the burden of proof and the amount of justification required to be produced by the state. Justice Clark in Baker felt that a showing of numerical disproportion was sufficient to shift the burden of justification to the state. Justice Harlan, on the other hand, thought that more was required to overcome the presumption of constitutionality. Since numerical equality is supposedly not required, it would seem to follow that a showing of disparity alone should not be sufficient. Perhaps the plaintiff must show "invidiousness," but this has not yet been defined. Invidiousness is at least intentional deprivation of equality. Under this limited definition the plaintiff would have to show that the discrimination is related to a purposeful design to favor one group over another. This could be shown, perhaps, by legislative refusals to apportion in the face of a state constitutional requirement. How much further invidiousness will be extended, however, is as yet undetermined. ${ }^{31}$

Nonrepresentation or gross disparities over a long period of time will probably be sufficient to place the burden on the state to justify its scheme even though no discriminatory intentions can be shown. Analogous situations can be found in Gomillion v. Lightfoot ${ }^{32}$ and the all white jury cases. ${ }^{33}$ Although no direct evidence of discrimination can be shown, the absence of Negroes from juries and jury rolls over an extended period raises a presumption that the absence does not result solely from the application of mechanical, neutral rules. Similarly, continued population disparities may raise a presumption that an impermissible classification factor has been employed.

29 Friedelbaum, supra note 25, at $69 \%$.

30 W.M.C.A., Inc. v. Simon, 370 U.S. 190, 191 (1962).

31 Courts have attempted to combine the Clark and Harlan approaches. See Moss v. Burkhart, 207 F. Supp. 885 (W.D. Okla. 1962). The court held that a showing of numerical disparity alone, without a showing of invidious discrimination, was not sufficient. Proof of a 10 to 1 disparity, however, stated a prima facie case. See also, Mann v. Davis, 213 F. Supp. 577 (E.D. Va. 1962) (showing of 4 to 1 disparity sufficient to place burden of justification on the state).

32364 U.S. 339 (1960).

33 E.g., Patton v. Mississippi, 332 U.S. 463 (1947); Norris v. Alabama, 294 U.S. 587 (1935). 
The analogy, however, is not perfect. Racial factors are not clearly involved in most apportionment cases. Assuming that some weighting is permissible, the analysis must penetrate beyond the numerical disparities themselves. Although Justice Harlan is probably correct in arguing that numerical disparities alone are not sufficient to invalidate an apportionment scheme, the state, and not the plaintiff, is in the best position to explain why disparities exist.

\section{I}

\section{STANDARDS SUGGESTED BY THE COURTS}

In attempts to implement Baker, courts have expressed a number of standards involving varying degrees of exactness. First, a fixed numerical standard has been employed by the Michigan Supreme Court in Scholle v. Hare. ${ }^{34}$ Armed with the United States Supreme Court's remand ${ }^{35}$ the Michigan Supreme Court struck down the senate apportionment scheme. ${ }^{30}$ Discrepancies in Michigan's senate representation were as high as 15 to 1. Less than one-half of the population elected two-thirds of the senate. The court held that any law that gives some citizens more than twice the voting power of others is unconstitutional. ${ }^{37}$

Although a 2 to 1 disparity was posited as an outer limit, the court did not imply that a lesser disparity was per se constitutional. ${ }^{88}$ Apparently a

84367 Mich. 176, 116 N.W.2d 350 (1962).

35 Scholle v. Hare, 360 Mich. 1, 104 N.W.2d 63 (1960), vacated and remanded, 369 U.S. 429 (1962).

${ }^{36}$ Scholle v. Hare, 367 Mich. 176, 116 N.W.2d 350 (1962). The court sharply split in each decision. The change in composition of the Michigan court that had occurred hetween the first and second decisions was crucial. Of the four memhers of the court who had joined in rejecting the plaintiff's case on the merits in the first decision, three still dissented despite Baker v. Carr. The fourth had resigned and his replacement, a former state attorney-general, disqualified himself. The fifth member, Black, J., had previously voted against the plaintiff, and his vote with the majority on remand was decisive.

The decision is also a result of fierce partisanship among the members of the court and in the state. It has been reported that the majority are Democrats and the minority are all Republicans. N.Y. Times, July 28, 1962, p. 9, col 2. See also, Ulmer, The Political Party Variable in the Michigan Supreme Court, 11 J. Pus. L. 352 (1962).

37 As a further aid to the legislature the court defined equal protection as follows: equality which fairly approximates, by the standards of reasonable minds exercising fair discretion, that which should have been done decemally between 1908 and 1952 and must now be done to ensure that reasonably uniform right of governmental representation which came to life by impact of the Declaration of Independence.

Scholle v. Hare, 367 Mich. 176, 189, 116 N.W.2d 350, 355 (1962).

$38 \mathrm{~A}$ similar approach has apparently been taken by the Rhode Island Supreme Court. Sweeny v. Notte, 183 A.2d 296 (R.I. 1962). The court struck down a state statute which complied with state constitutional requirements limiting the lower house to 100 members and providing at least one representative for each town or city.

The court used a representative ratio to point out inequities in the system. Rhode Island 
rational basis would still be required. Nevertheless, fixed standards seem out of place in constitutional analysis where flexible standards are usually imposed. A fixed numerical standard fails to allow sufficient flexibility to legislative choice based upon changing political and demographic conditions. Furthermore, if a numerical formula is used, there remains the problem of defining what kind of justification will be sufficient to explam a lesser departure from equahity.

Second, it has been suggested that states be prohibited from exceeding the disparities in voting power existing when they entered the union or the disparity suffered by any state through its representation in the United States Senate, whichever standard is higher. ${ }^{39}$ The use of a Senate representation standard would invalidate all plans in which less than 16.5 per cent of the voters elect a majority of the representatives. Reference to senatorial disparities, however, is only vaguely related to the problenl. The historical test would vary with each state, but its use would probably lead to less disparity than presently exists in most states. This standard, however, ignores the interest in voter equality which seems to be the focal point for the courts. Urbanization has radically altered the demographic complexion of most states since statehood, and the disparities existing when each state was admitted to the union do not seem relevent to the interests to be protected today.

Third, the state constitutional standard can be used. Many state constitutions, however, do not provide a population standard. Moreover, Baker specifically refused to consider the problem as the unequal application of state law. Thus a Federal standard will be used. In fact, some courts have held that the fourteenth amendment requires only "practical equality" even though the state constitution sets a strict population standard. ${ }^{40}$

New Hampshire's scheme for the apportionment of its senate involves a fourth standard-property ownership. The upper house is apportioned on the basis of equalized property valuations. ${ }^{41}$ Equalized valuation rep-

has a population of 859,488 . Thus, the ratio is 8594 to 1 (population $\div 100$ ). Eleven communities had a combined population of less than $3 \%$ of the state's population and were represented by $11 \%$ of the total number of representatives. The population of each of these commumities was such that their respective representative ratios were less than $I / 2$ of 8594 to 1 . Thus, reapportionment under the constitutional formula would only retain the inequality.

The court held that dilution of the vote of a majority of the electors to $\mathrm{T} / 4$ that enjoyed by the minority is invidious. The court thus provided an express maximal standard which is more generous than the standard expressed by the Michigan court. Probably, however, the court was merely stating its conclusion based on the situation before it.

39 Bonfield, supra note 16 , at 257-62.

40 Baker v. Carr, 206 F. Supp. 341 (M.D. Tenn. 1962); Moss v. Burkhart, supra note 31.

41 N.H. Const. Pt. II, art. 26th. Although the constitution phrases its standard in terms of "the proportion of direct taxes paid," the legislature's apportionment had been based on assessed property valuations. See Levitt v. Maynard, 104 N.H. 243, 182 A.2d 897, 899 (1962). 
resents the value of certain kinds of property. Thus the standard is not even a complete measure of wealth.

Although New Hampshire's senate districts had not been altered since 1915, the scheme was upheld by the state supreme court. ${ }^{42}$ The court was not "enchanted" with the system, but it found the plan rational. Surprisingly, the results of New Hampshire's scheme are less disproportionate than in most other states. ${ }^{43}$ Property values probably correlate to the degree of urbanism found in any state. ${ }^{44}$ It seems reasonable to expect commerce and wealth to congregate in urban areas.

The New Hampshire standard, however, appears to be undemocratic irrespective of the results achieved. The scheme does not seem related to any proper state interest, but rather affords "individuals a voice in government proportionate to their wealth or the wealth of those around them." ${ }^{\prime 4}$ Thus, the poorer a town or area is, the more persons and property will be included in the senate district, and each person's vote will be diluted because of the area's lack of wealth. The senate districts cannot be defended as historical or governmental divisions. Furthermore, property in a district may be owned by residents of another district or even by citizens of other states.

A fifth standard, an analogy to the electoral college, was employed by the district court in Gray v. Sanders. ${ }^{46}$ The three-judge court struck down Georgia's county unit system used to nominate candidates in primary elections for statewide offices and for the United States Senate. Under the system, each county was allotted a certain number of unit votes. ${ }^{47}$ A candidate was required to receive a majority of unit votes and a popular majority to be entitled to a nomination in the first primary. If no candidate received both a popular and a unit majority, the system provided for a runoff election in which the unit votes would control. Fulton County contains 14.11 per cent of Georgia's population but received only 1.46 per cent of the total 410 unit votes. Disparities were as high as 99 to 1 , and one-third of the population had a clear majority of the unit votes.

The district court enjoined elections under the system, requiring an election-at-large to be held. It did not, however, hold the system to be in-

42 Levitt v. Maynard, supra note 41.

43 The senate is controlled by $43.3 \%$ of the population and New Hampshire's three largest cities, containing $27 \%$ of the population, elect an average of $29 \%$ of the senators.

44 Baker, State Constitutions: REapportionMent 12 (1960).

45 Bonfield, supra note 16 , at 268.

46203 F. Supp. 158 (N.D. Ga. 1962), aff'd in part, 372 U.S. 363 (1962).

47 When the action was filed, Fulton County was allotted six unit votes. The eight largest counties by population received six votes, the next 30 received four unit votes, and the remaining 121 counties received two votes each. The Georgia legislature modified the system one day before the district court's decision by increasing Fulton's votes to 40 and the total unit votes fronı 410 to 547. GA. Code ANN. §§ 34-3212, 34-3213 (1962). 
vidious per se. Significantly the court provided an express numerical standard. The use of a unit system for primary elections would be deemed invidious if any county had less than its proportionate share of units to the nearest whole number. The system would not be invidious, however, if the disparity against any county was not greater than the disparity existing against any state in the electoral college allocation.

The electoral college analogy is clearly inappropriate. It would permit a disparity of 5 to 1 based on Alaska's three votes and New York's fortyfive votes. ${ }^{48}$ Even if this disparity is ignored, however, the analogy still has no real relation to the rights of Georgia voters. Two of Alaska's three votes represent its two senators, a non-population standard. The third vote represents Alaska's minimal representation as a governmental unit. Thus, all three votes are unrelated to Alaska's population. They merely signify Alaska's status as a state in the union and would remain even if its population should drastically decline.

A state should be required to present strong reasons to justify a 5 to 1 disparity; the existence of the electoral college is not alone sufficient. The analogy has no relation to the interests of the voters, and is a poor substitute for reasoned analysis. The same Georgia court wisely did not apply this standard to Georgia's legislative apportionment scheme, although the standard arguably has more relevance im a legislative context. ${ }^{49}$

The United States Supreme Court, in a remarkably brief opinion, affirmed the district court in Gray but rejected the electoral college analogy..$^{50}$ The Court held that any system that weights votes in state-wide elections is unconstitutional. "Once the geographical unit for which a representative is to be chosen is designated, all who participate in the election are to have an equal vote" no matter what their sex, race, occupation or place of residence. ${ }^{52}$ Justice Douglas, writing for the majority, stated that there was no "indication in the Constitution that homesite or occupation affords a permissible basis for distinguishing between qualified voters within the state." 53

48 Statistical Abstract of tale United States 352, 360 (1961).

49 Toombs v. Fortson, 205 F. Supp. 248 (N.D. Ga. 1962). The court merely stated that the considerations in the two cases were different and permitted no basis for an exact standard as in Gray,

50 Gray v. Sanders, 372 U.S. 368 (1962).

51 In rejecting even a modified umit system, the court said that even if "unit votes were allocated strictly in proportion to population" a candidate winning the popular vote in a county would receive the entire unit vote of that county. $I d$. at $381 \mathrm{n} .12$.

Maryland's use of the county umit system for primary elections has been held unconstitutional. Maryland Comm. for Fair Representation v. Tawes, 31 U.S.L. WeEK 2573 (D. Md. May 10, 1963).

52 Gray v. Sanders, supra note 50 at 379.

53 Id. at 380. 
The opinion was careful to state that the decision did not involve the degree to which the equal protection clause limits state legislatures in designing geographical districts from which representatives are chosen for the state legislature or the United States House of Representatives. "The present case is only a voting case." Georgia gives a vote to all "but in counting those votes she employs the county unit system which in the end result weights the rural vote more heavily than the urban vote ..."154

Despite the Court's warning concerning the limited scope of its opinion in Gray, the constitutional rule formulated seems broader than necessary under the facts presented. The Court stated that the "conception of political equality from the Declaration of Independence, to Lincoln's Gettysburg Address, to the Fifteenth, Seventeenth, and Nineteenth Amendments can mean only one thing-one person, one vote." ments mentioned by the Court only the seventeenth was conceivably involved in Gray. The Court, however, placed the decision under the fourteenth amendment. Justice Douglas does imply that the "one person, one vote" rule will not be applied to the apportionment area. He states, however, that the "only weighting of votes sanctioned by the Constitution concerns matters of representation, such as allocations of Senators ... and the use of the electoral college in the choice of a President. ${ }^{256}$ The quotation strikingly omits the area of state apportionment. ${ }^{57}$

Justice Douglas also implies that classification based on homesite is constitutionally invalid just as if the classification were based on race or sex. "How then can one person be given twice or ten times the voting power of another person in a statewide election merely because he lives in a rural area or because he lives in the smallest rural county." "58

Whether this statement will be repeated in the legislative apportionment context without the words "in a statewide election" remains a critical problem. There are reasonable distinctions between statewide and legislative elections. The officer elected in a statewide election represents the entire state and is responsible to all voters. Arguments for recognition of rural or minority interests in the legislative body have substantially less weight when applied to statewide positions. Furthermore, dilution is not necessary to secure geographical distribution of representatives as in the legislature, or to protect the historic integrity of governmental units.

54 Id. at 379.

55 Id. at 381 .

56 Id. at 380 .

57 In Baker, however, there are express statements that weigbting is permissible and that perfect equality is not required. 369 U.S. at 253 (Clark, J., concurring); 369 U.S. at 249 (Douglas, J., concurring).

58372 U.S. at 379. 
Justice Harlan, the lone dissenter, ${ }^{59}$ stated that justifications for the protection of rural voters applied in the Gray situation as well as in the legislative apportionment context." Finding no authority for the "one person-one vote" rule, he felt the Court was avoiding the problem of standards left undecided in Baker. The majority saw no need to consider Georgia's interest in the unit system; the Court's strict rule prohibits deviations from political equality. ${ }^{61}$

The state's interest in weiglting votes may well apply in both contexts, but the interest alleged to be injured is evidently different. The Court may well have balanced the interests involved, but as Justice Harlan implies, the opinion does not reflect careful particularization.

The traditional constitutional analysis would be to inquire whether there was a valid state purpose behind the legislation and whether the means used or classification employed was reasonably related to that purpose. To find that the unit system was not related to the legislative or electoral process, however, the Court would have to consider whether weighting of votes was proper. By suggesting that residence is analogous to race, the Court implied that the state's object was constitutionally impermissible. The ramifications of this implication and the scant historical precedent for the Court's "one person, one vote" rule would seem to warrant a more forthright analysis. ${ }^{62}$

Finally, many courts have invoked vague standards such as "invidious discrimination" or "rationality." These phrases have provided the framework within which courts have scrutinized legislative arrangements. Political equality is usually considered the starting point, and some variation from equality is permitted. The constitutional balance includes both the impact upon the individual's interests and the latitude given to the state to vary from equality. A number of cases illustrate this approach.

Upon remand, the three-judge district court in Baker v. Carr ${ }^{63}$ was faced with two new reapportionment acts hastily enacted after the Supreme Court's decision. ${ }^{64}$ The Tennessee constitution requires that representation

50 Justices Stewart and Clark wrote a brief concurrence emphasizing that the opinion did not involve the apportionment of state legislatures. Id. at 381. Justice Clark's statements in Baker that the Georgia umit system represented a rational scheme were not mentioned.

$60 I d$. at 382 .

61 Justice Harlan's interpretation of the majority's opimion as being applicable in an apportionment context may induce the majority to fulfill this belief. When asked about the meaning of a certain poem, Robert Browning is said to have replied, "I may not have meant it when it was written, but I mean it now."

62 See generally, Karst, Legislative Facts in Constitutional Litigation, 1960 Supreare Court Rev. 75 (Kurland ed.).

63 206 F. Supp. 341 (M.D. Tenn. 1962).

64 The Supreme Court's decision was handed down on April 23, 1963. 369 U.S. 186. The Tennessee legislature passed the apportionment acts on June 6,1962 in a special session. 
in both houses be based upon population. The court, armed with the state's own standard, rejected the new senate apportionment plan and conditionally accepted the lower house scheme. ${ }^{65}$

One statute provided that representatives for the lower house were to be apportioned among the counties on the basis of population, but any county with two-thirds of a ratio would receive one representative. ${ }^{.0}$ The court held that giving a measure of protection to a less populous governmental unit was not invidious per se. The counties were found to be integral and historic subdivisions of the state's governmental structure which have substantial interests in the state's laws. ${ }^{07}$ Thus, two related themes are expressed by the court: (1) governmental units may receive minimal representation because state laws affect them as units, and (2) historical patterns should be given some consideration in fashioning judicial standards.

The court, however, was not as tolerant with the senate reapportionment act. Thirty-three senatorial districts were established with no pretence of equality. Districts were not equal in area or population and there was great variation in the number of counties lumped together in the respective districts. One district contained 92,777 voters while another contained only 35,773. Furthermore, there was no uniformity among the rural or urban areas. One rural area had double the voting population of another rural area yet received no greater representation. Urban districts also varied in area and population.

The court held that at least one house should be based on the number of qualified voters without regard to any other factor. Thus, it refrained from fully enforcing the state standard. The court was unwilling, however, to perpetuate past evils by permitting malapportionment in one house. The two-thirds rule was held proper in one house only if the other house was based solely on population. Thus, if the two-thirds rule were maintained in the Tennessee House, the senate would have to be based solely upon population. Alternately, if the senate was apportioned on an equitable and rational basis not solely related to voting strength, the lower house must be apportioned upon population alone without regard to the two-thirds rule. ${ }^{68}$

65 The court held that the Supreme Court in Baker ruled sub silentio that invidious discriminations were present in the 1901 statute which violated the equal protection clause. 206 F. Supp. at 345.

$66 \mathrm{~A}$ representative ratio is found by dividing the number of voters in the state by the number of seats to be filled. See note 38 , supra.

67 The reapportionment of the lower house was held constitutional, but the court felt compelled to point out certain disparities. Two counties, given one representative because they contained a two-thirds ratio on the basis of total population, did not contain a two-thirds ratio based on their number of voters. Voting population was used for all other districts. The court apparently required a single population formula to be used throughout the state. $206 \mathrm{~F}$. Supp. at 346, n.7.

68 After setting guidelines, the court decided to give the legislature until 1963 to enact a fair apportionment scheme. 
The court's view that minorities can be protected without giving them majority power must be applauded. However, the court distressingly does not explain how its formula was derived. The test used is that "if a state legislative classification is wholly irrational and arbitrary, supported neither by the standard of the state nor any other standard, it is outside the permissible limits of the Fourteenth Amendment." ${ }^{\prime 69}$ Although one can quarrel with the court's wording, it is sufficient to note that the test hardly explains the unique guidelines set by the court. Explanation seems especially necessary since the legislature had attempted a partial correction of the evils created by its past inaction.

Affirmative judicial action was also taken by a federal court in Oklahoma which declared that state's constitutional and statutory provisions "prospectively null and void and inoperative for all future elections." The decision was followed by a supplemental order threatening judicial apportionment if the legislature did not apportion at the next general session. ${ }^{71}$ As this article went to press the court carried out its threat and reapportioned the Oklahoma legislature. ${ }^{72}$

Oklahoma's constitution provides for a population standard and requires reapportionment every ten years. No changes had been made, however, since 1910. Disparities were as high as 14 to 1 in the lower house and 26 to 1 in the senate. A majority of the senate represented 26 per cent of the state's population. Nine senators represented 52 per cent of the population, and the other thirty-five senators represented 48 per cent of the population. ${ }^{73}$

The court in its 1962 decision set "positive guidelines" for legislative action. "Substantial numerical equality" was held to be required under the

69206 F. Supp. at 344.

70 Moss v. Burkhart, 207 F. Supp. 885,898 (W.D. Okla. 1962).

The Oklahoma Supreme Court had held the 1961 Oklahoma House apportionment inconsistent with the state constitution but refused to enjoin elections under the system because disparities under the earlier statutes would be even greater. Jones v. Winters, 369 P.2d 135 (Okla.1961). The court later struck down the senate apportionment scheme and did enjoin the use of the scheme in subsequent elections. Reed v. State Elections Bd., 369 P.2d 156 (Okla. 1962).

71207 F. Supp. at 898-99. The November 1962 election was held not to be a future election. Judge Rizley strongly dissented, arguing that the court could not confer de facto powers on the state legislature. Unconstitutional acts, he argued, must be void $a b$ initio. See State ex rel. Tharel v. Bd. of County Comm'rs, 188 Okla. 184, 107 P.2d 542 (1940). See also Norton v. Shelby County, 118 U.S. 425 (1886). He also found no reason to beheve that the legislature would reapportion. 207 F. Supp. at 899-904.

72 Associated Press No. Al62KO. The court reached its decision "with reluctance." It apparently considered inadequate two plans the legislature had proposed. The court's plan is to become effective prior to the 1964 elections. Rural interests promised they would appeal the decision. Ibid.

73 At press time the effect the court's plan will have is not known. Apparently the court reapportioned strictly on the basis of population. Associated Press No. A162KO. 
United States Constitution. The "suffrage right of the individual is, and must be, the keystone--the common denominator, of self government."174 Other factors could be considered but none could overcome the basic principle of an individual's right to cast an "effective" ballot .The ultimate test used by the court, however, was hardly illuminating. It held that substantial equality would be approximately that voting power which is consistent with the Oklahoma and federal constitutions.

Another ambitious district court has prescribed its own apportionment scheme. ${ }^{75}$ The Alabama constitution requires that a population standard be used for legislative apportionment. ${ }^{76}$ The court initially held that representation in both houses had to be based upon population but withheld final relief. The state legislature, responding to the court's warning, voted to submit a proposed constitutional amendment to the voters and also passed a "stand-by" plan which would become effective should the voters defeat the amendment. Neither alternative, however, was to go into effect until 1966. The proposed amendment reduced the proportion of the population represented by the majority of the state senate from 25 per cent to 19 per cent. The scheme for the lower house adopted the present 105 man ceiling on representatives and required that one representative be elected from each county. Under the statutory scheme, 27.6 per cent of the population could control the senate.

Both the proposed constitutional amendment and the statutory alternative were held unconstitutional. ${ }^{77}$ Furth.ermore, the court held that there was no reason to postpone enjoyment of plaintiff's rights until 1966. Since the acts were passed in April 1962, however, the legislature could reasonably have decided that the November election was too soon to place the amendment before the voters. The members of both houses of the Alabama legislature are elected for four-year terms; ${ }^{78}$ the next election would be held in 1966.

Four days after it struck down the alternative plans, the court, to avoid harmful delay, issued its own apportionment scheme, combining parts of the proposed constitutional amendment and the alternative plan. ${ }^{70}$ It set the number of representatives for each county, adopting the scheme provided in the proposed amendment, and specified the composition of the senate districts, adopting the scheme in the statutory alternative. The court

74207 F. Supp. at 893.

75 Sims v. Frink, 205 F. Supp. 245 (M.D. Ala. 1962).

${ }^{76}$ AIA. CONST. art. IX, § 198.

77 Sims v. Frink, 208 F. Supp. 431 (M.D. Ala. 1962), prob. juris. noted, 31 U.S.L. WEEK 3404 (U.S. June 11, 1963) (Nos. 508, 540).

78 AxA. Const. art. IV, $\S 46$.

${ }^{79}$ Sims v. Frink, Civil Action No. 1744-N (M.D. Ala. decree filed July 25, 1962), prob. juris. noted, 31 U.S.I. WEEK 3404 (U.S. June 11, 1963) (No. 610). 
noted, however, that its extraordinary action was only temporary and called upon the legislature to enact "permanent" legislation. The court could not have been too enamored of its scheme since it had invalidated in toto the proposed amendment and statutory alternative from which its plan was taken. ${ }^{80}$

Even in de jure situations, where the legislative apportionment complies with state law, courts have had little difficulty striking down arbitrary schemes. In Toombs v. Fortson ${ }^{81}$ Georgia's legislative apportionment scheme and the statutory system for the election of state senators by rota-

80 More restrained courts have stayed judicial intervention pending possible legislative apportionment. See, e.g., Mikell v. Rousseau, 123 Vt. 139, 183 A.2d 817 (1962); Thigpen v. Meyers, 211 F. Supp. 826 (W.D. Wash. 1962); Wisconsin v. Zimmerman, 209 F. Supp. 183 (W.D. Wis. 1962).

The Vermont constitution limits the number of senators to 30 , yet permits each of its 14 counties to elect one senator. While one senator represents 18,606 voters another represents only 2,927. A majority of the senate is elected by $47 \%$ of the population. As time remained for the legislature to perform its duty to reapportion, the court in Mikell retained jurisdiction pending such action.

The apportionment of the Vermont lower house was not challenged although the disparities are glaring. Districts vary from a scant 38 persons to 33,115 persons. The majority of representatives are controlled by $11.6 \%$ of the population. Goldberg, The Statistics of Malapportionment, 72 YaIE L.J. 90, 101 (1962).

A district court in Wisconsin found discrimination in that state's legislative and congressional districts because of the state's failure to apportion after the 1960 census. Wisconsin v. Zimmerman, supra. Relief was postponed, however, because of the close proximity of the primary and general elections. The court advised the plaintiff that le could bring suit again if the legislature failed to reapportion in the 1963 session.

The Wisconsin constitution requires reapportionment after each census on the basis of the "number of inhabitants." WIS. ConsT. art. IV, § 3. The constitution limits the legislature to 100 assemblymen and thirty-three senators. The smallest fifty-one assembly districts have $40 \%$ of the population and the smallest seventeen senate districts have $42.5 \%$ of the population. The court would not characterize the scheme as invidious, but did say it was discriminatory. Yet, the dismissal seems based upon equitable considerations rather than on the merits. The court held that plaintiff had not presented a case for equitable relief. Other courts have employed this techmique to postpone a determination of the merits pending elections or possible legislative action. See Lisco v. McNichols, 208 F. Supp. 471 (D. Colo. 1962); Lein v. Sathre, 205 F. Supp. 536 (D.N.D. 1962).

In Thigpen v. Meyers, stipra, judicial intervention was also stayed. The Washington constitution requires apportionment every ten years "according to number of inhabitants." WASH. Const. art. 11, § 3. No legislative action has been taken to implement the constitutional standard simce 1901 .

Ninety-nine representatives and forty-nime senators are elected from forty-nine districts. Twenty-eight districts, containing $38 \%$ of the total population, are represented by a majority of the representatives in the lower house. Twenty-five districts, containing $35.6 \%$ of the population, elect a majority of the state senate. The disparity is almost 5 to 1 in the house and over 7 to 1 in the senate. The court held that disparities of such a "striking" nature were sufficient to overcome the presumption of constitutionality. The legislative scheme must be revised, but the court deferred action to afford the new legislature an opportunity to correct existing disparities.

81205 F. Supp. 248 (N.D. Ga. 1962). 
tion were struck down as invidious. With two exceptions, senatorial districts consist of three contiguous counties. ${ }^{82}$ Candidates for senator are elected in party primaries by each county in rotation ${ }^{83}$ and only voters in the candidate's county may vote in the primary. Senators cannot succeed themselves nor can a succeeding senator be from the same county as his predecessor. Thus, voters in two of the three counties cannot vote for candidates who would represent the senate district in which they reside. Although the system is strictly a nominating procedure, the court noted that nomination in a Georgia Democratic primary is tantamount to election.

No uniformity in size or population existed among the fifty-four senatorial districts, and the disparity was as high as 40 to 1 . The twenty-eight least populous senate districts elected a majority of the fifty-four senators while 55 per cent of the voters elected only twelve senators. The result of rotation in 1962 would be that 6 per cent of the voters could elect a majority of the senate.

The scheme in the Georgia House of Representatives was not much better. A 3-2-1 formula had been used by which the eight most populous counties received three representatives each, the thirty next largest recived two representatives, and the remaining 121 counties received one representative each. The counties vary in population from sparce Echols, with 1,876 voters, to populous Fulton County, with 556,326 voters. Representatives of the 103 least populous counties, containing 22.5 per cent of the population, have a constitutional majority in the lower house.

Faced with such great disparities, the court struck down the apportionment schemes of both houses. It held that at least one house must be based upon population. However, unlike Tennessee, the Georgia constitution does not express a population standard.

The court did not explain why the precise result was reached but did set out four considerations used in reaching it. First, is there a rational state policy? The court held that no evidence was presented to enable it to find that a policy exists which would justify disparities as great as 98 to 1 . Although the state may feel that political realities constitute a rational basis, the court did not consider this possibility. The court even attempted to speculate in order to find a rational policy, but it could only find a reluctance on the part of those with disproportionate power to surrender their advantage. ${ }^{84}$

82 The most populous county, Fulton, is an individual district, and Chatham County is joined with one other county to form a district. 205 F. Supp. at 250.

83 Ga. Code ANN. § 47-102.1 (Supp. 1961).

84 Toombs v. Fortson, 205 F. Supp. 248, 254 (N.D. Ga. 1962). This approach, often cmployed in reviewing economic legislation, seems more permissive than the "rationality" approach advocated by Justice Clark in Baker. Justice Clark's approach would place the burden upon the state to demonstrate that the disparities were justified by a rational plan. 
Second, is the scheme arbitrary? This question seems indistinguishable from the first, and the court admitted that a scheme is arbitrary if it is not related to a rational policy.

Third, does the scheme have a historical basis? The 3-2-1 formula had been employed since 1868, and reapportionment on that basis had been achieved every ten years. The court, however, decided that there was no reason to continue a scheme merely because it had a historical basis, especially when population shifts have destroyed any rationality the system once may have had. Evidently, the court treated the existence of a historical basis for the scheme as a consideration to be used in determining rationality and not as a separate factor.

Fourth, are there political remedies available? Georgia provided neither initiative nor referendum. Even if these remedies had been available, it is doubtful that the decision would have been different..$^{85}$

Thus, rationality seems to be the court's only test. Significantly, the court felt the scheme offended "fundamental political concepts inherent in a republican form of government.".86 The difficulties of stretching equal protection to provide the necessary standards seems to have been recognized. As far as standards are concerned, however, the court informs us only that a disparity of 98 to 1 is "so excessive as to be invidious."

As Justice Frankfurter admonished in Baker, "One cannot speak of 'debasement' or 'dilution' of the value of the vote until there is first defined a standard of reference as to what a vote should be worth." ${ }^{\prime 8}$ Recognizing that there must be some basis from which deviation from equality can be measured, ${ }^{89}$ the post-Baker courts have attempted to establish "substantial numerical equality" as a general norm. ${ }^{90}$ The Toombs court and others have used voter equality as the starting point of their analysis even though the articulation of the standard is not always clear.

The sources of this standard are shadowy and explanations, as Gray v. Sanders ${ }^{91}$ has shown, lead to generalized statements of equality found in historical documents. Traditional ideals of representative democracy and government by consent can be inarshalled to defend the standard, but, as

85 See notes 107-18 infra and accompanying text.

86 Toombs v. Fortson, supra note 84 , at 256 .

87 Ibid. After Toombs was decided, a new apportionment law for the state senate was signed into law on October 5,1962 . The 54 districts now vary from 57,000 persons to 82,000 , and the nine most populous counties containing $43 \%$ of the population elect $40 \%$ of the senators. Brief for the Umited States as Amicus Curiae, p. 49, n.23, Gray v. Sanders, 372 U.S. 368 (1962).

88369 U.S. at 300 (dissenting opinion).

89 Id. at 299.

90 E.g., Moss v. Burkhart, 207 F. Supp. 885 (W.D. Okla. 1962).

91372 U.S. 368 (1962). 
Justice Frankfurter pointed out, there has been considerable indifference to political equality in the apportionment area. Long indifference to what are generally conceded to be fundainental rights, however, may actually induce judicial action, as Brown v. Board of Education ${ }^{22}$ demonstrates.

The use of history in the segregation cases can be usefully contrasted with the approach taken in Baker and Gray. In Brown reargument had primarily been directed to the historical circumstances surrounding the adoption of the fourteenth amendment in 1868. Chief Justice Warren found, however, that although history cast some light upon the problem, the sources were inconclusive. ${ }^{93}$ Furthernore, the clock would not be turned back to

1868 when the Amendment was adopted, or even to 1896 when Plessy $v$. Ferguson was decided. We must consider public education in the hight of its full development and its present place in American life throughout the Nation. Only in this way can it be determined if segregation in public schools deprives these plaintiffs of equal protection of the laws..$^{04}$

Thus, the Court decided to start afresh and founded its decision on a review of considerations existing in the mid-twentieth century.

Similarly, the Court in Baker and Gray could have viewed the problem as an analysis of the impact of malapportionment upon democratic processes. Indeed, history seems even less helpfill in the apportionment area than in the segregation field. Nevertheless, the Court in Gray indicated that it will wrap this new development of substantive protection in the shadowy blanket of history. The result in Brown, however, was probably more predictable than that in Baker, especially in the light of prior cases. Furthermore, the Court's reliance on history in Gray may be a factor of the sharp split on the Court and the novelty of the issues and remedies involved. ${ }^{95}$

Irrespective of the problems of origin involved in a standard of "substantial numerical equality," this vague standard will probably carry the day. The success of the states in avoiding numerical equality will depend upon their ability to present evidence of the rationality of non-population considerations. This, in turn, will depend upon the interests considered relevant by the courts.

92347 U.S. 483 (1954).

93 Id. at 489 .

94 Id. at $492-93$.

95 The brevity of the opinion in Gray and the brisk reference to the sources of the Court's rule of equality is reminiscent of a comment made about Brown v. Board of Education. "[T] less said, the less chance of internal disagreement. By the same token, it was wise to present as small a target as possible to marksmen on the outside." Bickel, The Original Understanding and the Segregation Decision, 69 HaRv. L. REv. 1, 2 (1955). 


\section{II}

\section{THE INTERESTS AT STAKE}

Where a justification for varying from a population standard is presented, the court must imquire into the reasonableness of the classification used as well as the purposes of the scheme. The plaintiff's interests must be weighed against the interests of the state. At present the composition of both sides of the balance is unclear.

\section{A. The Voter's Interest}

The voter claims that all voters in the state must be treated alike and that he must be given equal, or at least fair, representation in the state legislature. The right to vote and the right to have each ballot counted undiluted by fraud ${ }^{98}$ have been recognized. The right to have a vote count as much as any other vote, in legislative elections, is not yet established.

The touchstone of the voter's claim is really the principle that one man equals one vote. Although the principle enunciated in Gray was limited to statewide elections, the opinion suggests that voter equality will at least be the starting point of analysis in apportionment cases.

While it has been argued that alleged malapportionment actually involves injury to a group of voters who claim that their rightful political influence has been arbitrarily diluted, ${ }^{97}$ the courts have thus far treated the cases as involving individual claims of deprivation of political influence. ${ }^{98}$ The voter claims that his vote is diluted by an irrational state classification. He probably does not represent all of the voters within the injured group, since some of them may favor the existing situation on political or philosophical grounds. Admittedly, voters in these suits are speaking for voters in areas which receive scant representation in the state legislature, but the discrimination affects each voter, just as surely as if racial lines had been drawn. The mjury to Negroes caused by discriminatory voter qualification test is a personal one, even though the general aim of a voter drive miglit be to secure substantial representation for the whole Negro population. The individual's claim should not be weakened because a larger goal is also benig sought. The parallel rests, however, on the debatable

86 Ex parte Siebold, 100 U.S. 371 (1879).

97 Baker v. Carr, 369 U.S. 186, 298-300 (1962) (Frankfurter, J., dissenting); see also Neal, Baker v. Carr: Politics in Search of Law, 1962 Supreare Court Rev. 252, 274.

88 One court has denied relief on standing grounds. League of Nebraska Municipalities v. Marsh, 209 F. Supp. 189 (D. Neb. 1962). The court held that mayors acting in their official capacity, a state labor council, and an organization composed of $1 / 2$ of the state's incorporated municipalities had no standing because they were neither voters nor agents of voters.

Two courts have denied injunctive rehef because no irreparable harm was shown. Valenti v. Dempsey, 211 F. Supp. 911 (D. Conn. 1962); Sincock v. Terry, 210 F. Supp. 396 (D. Del. 1962). 
assumption that racial classification and residence are analogous. As mentioned above, ${ }^{99}$ Gray hinted that such an assumption will be made.

The existence of an individual interest in voter equality bears on the problem of political remedies. Justice Clark, in Baker, felt that he "would not consider intervention by the Court into so delicate a field if there were any other relief available to the people of Tennessee." 100

In W.M.C.A., Inc. v. Simon, ${ }^{101}$ plaintiffs challenged the minimum representation given to all but one of New York's counties in both houses of the legislature. ${ }^{102}$ New York provides a means of political change by way of a constitutional convention. ${ }^{103}$ New Yorkers, however, declined to call a convention in 1957. Although 36.9 per cent of the state's population could control the state senate, the court upheld the scheme, holding that it did not treat urban and rural areas differently. The assembly was held to be based "substantially" on population even though the disparity was as high as 13 to 1 .

Although other considerations were involved, ${ }^{104}$ the existence of a polit-

99 See note 58 supra and accompanying text.

100 Baker v. Carr, supra note 97 , at 258-59 (Clark, J., concurring).

101208 F. Supp. 368 (S.D.N.Y. 1962), prob. juris. noted, 31 U.S.L. WEEK 3404 (U.S. June 11, 1963) (No. 460). The court had dismissed the case earlier, but the Supreme Court remanded in light of its decision in Baker. 202 F. Supp. 741 (S.D.N.Y. 1962), vacated and remanded, 370 U.S. 190 (1962).

102 New York's senatorial districts are combinations of counties or parts of counties which should approximate a ratio found by dividing the state's population hy fifty, the minimum number of senate seats. The total number of seats is increased from fifty when any county is entitled to more than three representatives. No county can have four or more senators unless it has a full representative ratio for each member. Each district is required to he compact in area and to contain approximately equal numbers of voters.

103 N.Y. ConsT. art. 19, § 2.

104 First, the court deferred to a historical policy which provided for county representation. Although some representation might be historically justified, the question remains whether the small counties elect a disproportionate number of assemblymen. Furthermore, this historical pattern has no application to New York's senatorial districts, since they are composed of more than one county or parts of counties.

Second, the court found no geographieal discrimination. It was proper, the court found, to diffuse political initiative between thinly populated and populous areas. A strict population standard would increase the size of the assemhly and hamper debate. If districts were enlarged, contact hetween legislators and their constituents would be impaired.

Basic to the court's decision was the fear that populous New York City would control the legislature and would not be sympathetic to the problems and needs of the remainder of the state. Judge Ryan, concurring, stated that $3 \%$ of the state's area would dominate the rest of the state if a population standard were to be used. 208 F. Supp. at 384 (Ryan, J., concurring). Surely though, "area" does not dominate. That an area is not represented, or is underrepresented, should only be relevant if the people residing in that area have specific needs which are not being attended to by the legislature. Undoubtedly, however, courts use "area" as a symbol behind which other interests are protected, such as farming or lumbering interests. Yet, it is precisely these interests that are usually represented by powerful and well organized lobbies. 
ical remedy was, perhaps, critical to the court's decision. The court noted that the electorate had voted in 1957 against calling a constitutional convention, even though the six counties represented by the plaintiffs contained 56 per cent of the state's population. It also stated that the ten most populous counties could control a constitutional convention. Although voters were not voting specifically on apportionment, the vote was "heralded as an issue of apportionment."105 Nevertheless, the voters were not voting on a specific plan or districting scheme. Furthermore, the court seems caught in the web of statistics. It is very doubtful that every voter in the six counties voted, or, if they did, whether they voted for the convention. If the present scheme favors one political party, as can be expected, members of the favored party residing in disfavored counties may not want the system altered. Notably, one district court has used the existence of a political remedy and its defeat at the polls to justify judicial action. ${ }^{106}$

In Michigan, the voters, by referendum, had frozen senatorial districts by approving a scheme which included no provision for subsequent alterations based on population changes. In contrast to W.M.C.A., the Michigan Supreme Court struck down ${ }^{107}$ the state's senate apportionment scheme even though a political remedy existed and had, in fact, been exercised. The court, because it was a state court, may have felt less restrained than the federal court in New York. The partisan attitude of the Michigan judges ${ }^{108}$ and the approaching election may also have been relevant.

It is doubtful that the Supreme Court will subscribe to Justice Clark's suggestion. First, although the presence of other remedies may have equitable implications, it does not remove numerical disparities present in a state. If these disparities are deemed to violate protected interests, how can the Court deny relief? Even if the presence of remedies is made part of the constitutional balance, it seems unrelated to the rights allegedly infringed.

Second, twenty states presently have provisions for the passage of legislation by the initiative or referendun. These states would not be subject to the implications of Baker if the political remedy consideration were to be adopted. Other states may be willing to adopt such measures specifically to avoid Baker. Even so, the Court would have to determine whether the devices themselves were tainted with malapportionment. Furthermore, the referendum alone is not sufficient where the legislature submits the issue to the electorate. ${ }^{109}$

105208 F. Supp. at 378.

108 Moss v. Burkhart, 207 F. Supp. 885 (W.D. Okla. 1962).

107 Scholle v. Hare, 367 Mich. 176, 116 N.W.2d 350 (1962).

108 See note 36 supra.

${ }^{100} \mathrm{~A}$ referendum asking whether a constitutional convention should convene was overwhelmingly approved in a 1950 general election in Maryland, 200,000 to 70,000. Bills to make the proposal operative, however, were tabled at the next session of the Maryland General Assembly. 
The problems are compounded by the apparent inadequacy of the referendum and initiative. As pointed out above, Michigan voters adopted a scheme which caused great disparities. The Constitution, of course, protects ininorities as well as majorities. Thus, even though a particular scheine may be adopted by the majority of voters, an injured minority can challenge the measure. Perhaps this consideration is irrelevant where plaintiffs claim that the inajority of voters are not given their fair voting power, but it seems unfair to penalize voters in populous counties because residents of the same counties may have voted against reapportionment. The question, except in class actions, is still whether the rights of the plaintiff as an individual have been infringed.

A number of courts apparently have treated the problem in this manner. An Oklahoma district court, noting that previous initiative measures had been defeated at the polls, asserted that the rights claimed by plaintiffs could not "be made to depend upon the will of the majority."110 A district court in Washington refused to decline jurisdiction where the voters had defeated an initiative measure designed to reapportion the legislature according to population in the November 1962 general election. Repeating the phrase quoted above, the court proffered that some voters may have favored reapportionment but either did not understand the initiative proposal or disagreed with the particular method proposed. ${ }^{111}$ The court realized, however, that the existence of a political remedy was irrelevant to its decision.

Initiative measures have failed on various legal and political grounds. A Massachusetts court declared that the initiative and referendum were not applicable to the creation of state senatorial and representative districts. ${ }^{112}$ The Missouri Supreme Court nullified an apportionment by initiative. ${ }^{113}$ The failure in California in 1948 to secure reapportionment by initiative shows that some urban interests favor inaction or reapportionment. Four of the most populous counties voted against reapportionment by two to one margins and Los Angeles County defeated the measure by almost the same margin. ${ }^{114}$

A statutory initiative has been used successfully to force reapportionment upon an inactive legislature only twice. (Washington, 1930, and Colorado, 1932. $)^{115}$ In Washington a popularly initiated and ratified reappor-

110 Moss v. Burkhart, supra note 106 , at 894 .

111 Thigpen v. Meyers, 211 F. Supp. 826, 832 (W.D. Wash. 1962).

112 In re Opinion of the Justices, 254 Mass. 617,151 N.E. 680 (1926).

113 State ex rel. Halliburton v. Roach, 230 Mo. 408, 130 S.W. 689 (1910).

114 See Barclay, The Reapportionment Struggle in California in 1948, 4 WesterN Por. Q. 312, 313 (1951). See generally, Harvey, Reapportionment of State Legislatures-Legal Requirements, 17 LAW \& CoNTEMM. Pro3. 364, 373-76 (1952).

115 Silva, Apportionment in New York, 30 FordhaM L. REv. 581 (1962). 
tionment in 1956 was radically altered by the legislature. The Washington Supreme Court upheld the legislative scheme.110

Washington's experience raises another objection. Is the political remedy sufficient if it merely exists on the statute books or need the remedy also be adequate? What should adequacy mean in this context? Courts have generally not treated the presence of remedies as critical, and schemes have been struck down even though remedies were available. ${ }^{117}$

The initiative may also be impractical because of the resources necessary to place a proposal on the ballot. This point was emphasized by a federal court in Nebraska. ${ }^{118}$ The court noted that a voter must draft the proposed amendment and then must acquire the signatures of 10 per cent of the electors if he proposed a constitutional amendment. The court held that the expense was prohibitive for the "ordinary voter." Although more than one voter brought the action, the court felt the "ordinary voter" was the proper standard since one voter could maintain such an action. The court apparently treated the "adequacy" of the remedy as a traditional equitable consideration.

Although the existence of political remedies will probably not be used as a bar to a voter's action, it may be considered as a factor to be weighed as in W.M.C.A.

The most effective weapon in the voter's arsenal has been the existing numerical disparity. The chief element is the percentage of the total number of voters who are able to elect a majority of the representatives. The relative value of a vote in a large district as compared to a small district and the representative ratio have also been considered relevant.

Justice Harlan's argument that a strict mathematical formula cannot be used certainly has merit. The use of a "purely statistical approach" would fail to "take account of the fact that a multitude of legitimate legislative policies, along with circumstances of geography and demography, could account for the seeming electoral disparities among counties."119 Nothing in Baker or Gray expressly denies that "non-population" factors may justify some disparities.

On the other hand, the use of statistics to show that no invidious discrimination exists often contains hidden traps. The use of population figures to show that the underrepresented could control a constitutional convention or could have insured the success of an initiative proposal glosses

116 State ex rel. O'Connell v. Meyers, 51 Wash. 2d 454, 319 P.2d 828 (1957).

117 Moss v. Burkhart, 207 F. Supp. 885 (W.D. Okla. 1962); Scholle v. Hare, 367 Mich. 176, 116 N.W.2d 350 (1962).

118 League of Nebraska Municipalities v. Marsh, 209 F. Supp. 189 (D.Neb. 1962).

119 Baker v. Carr, 369 U.S. at 345 (Harlan, J., dissenting). "To assune that political power is a function of numbers is to disregard the practicalities of government." MacDougall v. Green, 335 U.S. 281, 283 (1948). 
over the fact that some residents of underrepresented areas favor the status quo. Furthermore, the use of averages may disguise glaring individual disparities.

Another weakness in a purely statistical approach is the assumption that rural and urban $^{120}$ groups vote in solid blocs. The notion that urban voters tend to vote Democratic and rural voters tend to vote Republican may be, in general, plausible. There are certainly sufficient exceptions, however, to prohibit the use of such a dubious assumption in constitutional analysis. Furthermore, it cannot be argued that the representatives of the rural minority and the urban majority will always vote as competing blocs, even when urban legislation is primarily involved.

The scope of the voter's interest may extend beyond the pure apportionment area. Even though a state creates districts of equal population or gives existing political units proportionate voting power, lines can still be drawn so that one political party receives less than its proper share of legislative seats. The object is to "maximize the number of districts returning safe majorities for the apportioning group" by combining the party's weak or scattered voters, spreading out its voters to capture more districts, or by confining the opposing party's voters to as few districts as possible. ${ }^{121}$ This is called "party strength malapportionment" or, simply, gerrymandering. ${ }^{122}$ This device, containing artistic and scientific qualities, is not usually considered as evil as malapportionment. The problems inherent in gerrymandering, which are outside the scope of this article, deserve fresh analysis in the light of recent developments, because this device can create results similar to those created by malapportionment. ${ }^{123}$

120 The "rural-urban" characterization is used as a Jabel here to include the major competing electoral groups found in any state.

121 See Lewis, Legislative Apportionment and the Federal Courts, 71 HARv. L. REv. 1057, 1059 n.10 (1958); Grazia, General Theory of Apportionment, 17 LAw \& ConteMp. Prob. 256, 263 (1952).

122 See Epsten, PoLITICs IN Wisconsin 122-25 (1958); Harver, Reapportionment and State Legislatures, 17 LAw \& Contenrp. Prob. 368-69 (1952). For some of the problems created by gerrymandering, see Lewis, supra note 121, at 1063-66; Sindler, How to "Sear the Conscience" of Legislators, 72 YALE L.J. 23, 24-28 (1962).

123 A post-Baker gerrymander case has recently been decided by a district court in New York. Wright v. Rockefeller, 211 F. Supp. 460 (S.D.N.Y.1962), prob. juris. noted 31 U.S.L. WeEK 3404 (U.S. June 11, 1963) (No. 950). The plaintiffs asserted that Manhattan's four congressional districts had been gerrymandered aJong racial lines. The court, however, held that the districts were not invidiously drawn because the plan was based on population. The court's opinion provides httle restraint on racially-based districting as long as population disparities are not significant.

The 17th district of Manhattan has 70,000 (12-15\%) Jess voters than the island's other three districts. These latter districts contain $97 \%$ of the island's non-white population. The 17th, or "silk stocking" district, is carefully drawn to ensure the election of at least one Republican Congressman from the predominantly Democratic island.

Interestingly, however, the suit was not dismissed, although congressional districts were 
The voter's interest may also be held to extend to congressional districts. A number of courts, however, have held that Baker distinguished Colegrove v. Green ${ }^{124}$ on the ground that the latter was concerned with congressional districts. Since congressional elections involve grants of authority to Congress, a coordinate branch of the federal government, the matter is therefore deemed a political question. ${ }^{125}$

This interpretation of Baker is subject to serious doubt. Article 1, section 2, of the fourteenth amendment does not clearly state that Congress is to have exclusive or even primary control over congressional districting. Districting is performed by the states and court orders would be directed at state officials. Although some authority is vested in Congress, the states are not relieved thereby of the obligations of the fourteenth amendment.

involved, and the court reached the merits. Furthermore, the plaintiffs did not claim that the apportionment scheme diluted their voting strength. Their claim, based upon Gomillion v. Lightfoot, 364 U.S. 339 (1960), was that substantially all of the non-white population were included in the 18th, 19th, and 20th districts. The percentage of non-whites in the 17th, 18th, 19th, and 20th districts was $3.1 \%, 58.2 \%, 19.8 \%$ and $18.9 \%$, respectively. Any expansion of the 17th district in any direction would apparently require the addition of non-white areas.

The voters asked the court to conclude that district lines had been intentionally drawn to exclude non-whites. The court rejected the claim, holding that there was no evidence of bad intentions and that there had been no deprivation of the right to vote. In Gomillion, however, there was also no direct evidence of discrimination, but, as in the all white jury cases, the results spoke for themselves. Furthermore, the lack of a fifteenth amendinent claim has no effect on equal protection under the fourteenth amendenent. The right to vote was not lost in Gomillion, but the right to vote in a certain area was lost because racial lines had been drawn. The parallel to Gomillion at least exists, and the dissenting judge felt that Gomillion dictated the result in this case.

It is generally admitted that the 17th district is designed to elect a Republican from Manhattan, but it would be facetious to argue that only party affiliation and not race is considered in the delimitation of this district; the non-white population of Manhattan generally votes Democratic. Perhaps non-white control of one district would be jeopardized, but, even if a court could take cognizance of such a possibility, "fair" districts could give non-white groups, approximately $40 \%$ of the borough's population, substantial participation in all four districts. For a thorough analysis of this problem, see Wright $v$. Rockefeller and Legislative Gerrymanders: The Desegregation Decisions Plus a Problem of Proof, 72 YaIE L.J. 1041 (1963). See also, Honeywood v. Rockefeller, 214 F. Supp. 897 (E.D.N.Y. 1963), where a similar challenge failed because of a failure of proof.

124328 U.S. 549 (1946).

125 Wesberry v. Vandiver, 206 F. Supp. 276 (N.D. Ga. 1962), prob. juris. noted, 31 U.S. L. WEER 3404 (U.S. June 11, 1963) (No. 507). Georgia was divided into ten districts for its ten congressional seats in 1931 but no alterations in the districts have been made since that date. Although the disparity was 3 to 1 and the system had become "arbitrary" through legislative inaction, the court felt that a political remedy was possible because the legislature would be fairly apportioned after its decision in Toombs.

The same position bas been taken by the Florida Supreme Court. Lund v. Mathas, 145 So. $2 \mathrm{~d} 871$ (Fla. 1962). The court held that inere variations in district population from 327,000 to 660,000 was not sufficient to prove a claim of violation of rights. See also, Wright v. Rockefeller, supra note 123; Thigpen v. Meyers, supra note 111; Preisler v. Hearnes, 362 S.W.2d 552 (Mo. 1962). 
Moreover, Baker expressly stated that Colegrove was based upon a want of equity. ${ }^{126}$

\section{B. The State's Interests}

The structure of apportionment cases makes the clarification of the competing interests difficult. The defendants are usually state officials with only ministerial roles in the electoral process. Furthermore, the defendants are normally represented by the state's executive branch. This branch, representing a statewide constituency, tends to sympathize with the interests of the plaintiff. ${ }^{127}$ This places a greater burden on the court and often induces legislative groups or interest groups to intervene in the suit.

The state inay initially present three arguments in an attempt to prevent judicial review of the substantive elements of apportionment. First, it may einphasize the existence of political remedies. As mentioned earlier, ${ }^{128}$ the existence of such remedies will probably not be a bar to judicial relief although the availability of remedies may have some effect on the balancing process.

Second, the state may assert a desire to be free of the restraint of rationality. More precisely, it may argue that the apportionment scheme is rational because it was arrived at through legislative processes. Political considerations and the genuine need for compromise may indeed be rational and yet lead to a scheme containing great numerical disparities. Thus, rationality may include considerations leading to the passage of a particular scheme as well as the consistency of the final result. Perhaps the results reached by arbitration or collective bargaining would be analogous.

The courts apparently are not willing, however, to grant the legislators a great deal of freedom to coinpromise. The rationality inquiry has been directed to the finished product, and all parts must reasonably fit together. Thus, a scheme inay be reasoned and, therefore, more than "no policy,"120 and still be found unconstitutional. To be sure, the courts recognize that some disparities will exist because of political exigencies, but this recognition will not be permitted to excuse gross disparities. This is a practical approach and perhaps explains why courts stress that the Constitution sets only maximum limits. Moreover, the courts cannot determine whether a compromise is bona fide or merely represents the refusal of a minority to surrender disproportionate power. The compromise itself may be based on interests which are not constitutionally recognized.

Third, the state nay argue that review is limited to the consistency of

128369 U.S. at 234.

127 Neal, supra note 97 , at 273 .

128 See notes 107-18 supra and accompanying text.

129 Baker v. Carr, 369 U.S. 186, 226 (1962). 
the state's actions. As apportionment is admittedly within the state's traditional sphere, the values advanced by the state should be given deference if the plan adopted is reasonably adapted to carry out the state's purposes. It is difficult to conceive of consistency as the boundary of judicial review in apportionment cases, but it is at least an important consideration.

Thus, Justice Clark found disparities existing among rural areas in Baker to be evidence of irrationality. ${ }^{130}$ This can be called "horizontal" disparity as compared to "vertical" disparity between rural and urban areas. This consideration is complicated by the difficulty of defining "urban" or "rural." The dispersion of industry and growth of cities has blurred the line between rural and urban areas in many instances. This precise difficulty, however, weakens a state's claim that it desires to protect rural voters.

One writer has considered the "horizontal" analysis ineffectual because the states can alter their schemes to avoid its impact. ${ }^{131}$ This criticism seems unwarranted. The "horizontal disparity" consideration is only one element of the analysis involved in determining whether a state's scheme has a rational basis. It is certainly useful when a state claims an interest in protecting rural interests. The court, then, is merely checking to see if the "means used" effectuate the scheme's alleged purpose. That states may correct their scheme is no objection. If the disparities are increased, further justification will still be necessary.

A second aspect of consistency is whether the districts used have any independent significance. Before Gray, Justice Clark proferred that Georgia's county unit system represented a rational state policy because traditional county limes were used. Some states use counties as districts for the lower as well as the upper house. This use often depends on the number of counties in the state or the number of seats to be allocated. Thus, a state with a maximum of 100 representatives but containing 150 counties will undoubtedly not use a pure county system. Often, then, counties are combined to form larger districts. These fortuitous circumstances are slin reeds upon which to base constitutional distinctions. Furthermore, requiring consistency could encourage states to use more rigid districting schemes. The use of counties, rather than districts composed of a number of counties, could cause greater disparities.

Furthermore, counties are mere political and administrative subdivisions of the state created as convenient agencies for exercising certain governmental powers. There is nothing inherently unalterable in a county's borders; their permanence, for purposes of the federal constitution, "rests 
in the absolute discretion of the State."132 This is not to say that historical divisions should not be considered. The state's power to alter boundaries is limited by the fourteenth and fifteenth amendments. ${ }^{133}$ There may also be state legal obstacles in the way of boundary changes. In any event, county boundaries which have remained relatively constant for many years should be afforded some legal weight. Counties exist to perform certain functions, however, and it may be argued in a particular case that the county has lost its utility as an electoral district. Indeed, counties have proved functionally inappropriate to perform certain public functions. ${ }^{\mathbf{1 8 4}}$ If the county no longer has relevance to the electoral process because of population shifts, it should be discarded. ${ }^{185}$

The third aspect of consistency involves the use of history. Many courts have used history as an independent consideration. ${ }^{136}$ Yet, the first court to so use it ${ }^{137}$ retreated in a later case ${ }^{188}$ by holding that historical precedent alone was not sufficient. The court realized that the pattern must still be rational. This limitation also applies to the use of counties as districts, mentioned above. Historical precedent should probably be considered in determining rationality, but should not be a separate criterion.

In addition to these three initial arguments, the state may advance an interest in weighting certain votes differently by using non-population factors. Like eminent domain, apportionment and boundary drawing are devices available to the state to accomplish certain governmental objectives. ${ }^{139}$ States have traditionally exercised wide latitude in creating electoral districts. Now, however, judicial scrutiny will be directed at the justification for political inequality. The outer limits should vary with the considerations advanced to justify the inequality. ${ }^{140}$ Thus far, courts have determined the amount of equality which should exist rather than the extent to which the inequality may be justified by certain non-population factors. ${ }^{141}$ The state's justifications for inequality are surely part of "ra-

132 Hunter v. Pittsburg, 207 U.S. 161, 178 (1907).

138 Gomillion v. Lightfoot, 364 U.S. 339 (1960).

184 ForDHAM, LOCAL GOVERNMENT LAW 25-27 (1949).

$185 \mathrm{~A}$ parallel arises in many areas of the law where categories, conceived in one contcxt, are forced to do service in another context. Professor Lynn of Ohio State Law School aptly terms this phenomenon "hardening of the categories."

136 W.M.C.A., Inc. v. Simon, 208 F. Supp. 368 (S.D.N.Y. 1962), prob. juris. noted, 31 U.S. L. WeEk 3404 (U.S. June 11, 1963) (No. 460); Sanders v. Gray, 203 F. Supp. 368 (N.D. Ga. 1962).

137 Sanders v. Gray, supra note 136.

138 Toombs v. Fortson, 205 F. Supp. 248 (N.D. Ga. 1962).

${ }^{139}$ Lucas, Dragon in the Thicket; a Perusal of Gomillion v. Lightfoot, 1961 Supreare Court REv. 194, 214 (Kurland ed.).

140 Brief for the United States as Amicus Curiae, pp. 30-35, Baker v. Carr, 369 U.S. 186 (1962).

141 Baker v. Carr, 206 F. Supp. 341 (M.D. Tenn. 1962) ; Toombs v. Fortson, supra note 138. 
tionality," but the states apparently have not been willing or capable of demonstrating a rational basis for their schemes. ${ }^{142}$

One interest which has been recognized is the desire to give recognized political units at least mimimal representation. This is often justified by reference to the number of special acts passed by the state legislature which directly affect local units or by reference to historical precedent. The fear is that urban voters, for instance, will not understand the needs of nonurban areas. For examples of this kind of evil, one need only look at the reverse situation which exists in many states.

Minimal representation has received strong approval by a district court in Florida. ${ }^{143}$ In August 1962, the court held the Florida constitutional and statutory apportionment provisions existing up to 1962 null and void. Relief was withheld, however, pending possible legislative action. No reasons were given for determining the provisions "invidious," and the state constitution does not provide a population standard. The disparities, however, were great. ${ }^{144}$

Meeting in extraordinary session, the Florida legislature responded with a proposed apportioninent plan to place before the voters in November 1962. The plan provided for one representative to be elected from each county with additional representatives distributed by representative ratios. The senate plan provided for districts composed of two or more counties. The court held both plans to be rational.

The court employed a general standard of rationahity, and held that this standard could include a number of factors im addition to population. Each Florida county had historically elected one representative since statehood, but the thrust of the court's approach was directed at the practicality of minimal representation for governmental units.

In the Florida legislature's 1961 session, 1,266 special acts were passed relating to counties and municipahities. It was held rational, therefore, for the state to conclude that this function of government could not be adequately performed if a substantial number of small counties had no representation. Minimal representation was recognized in Baker but only for units containing two-thirds of a population ratio. In Florida, however, units with an even smaller proportion would be represented and greater disparities would be created. Moreover, vital questions went unanswered. What proportion of all legislative action is directed at counties and inunicipalities by way of special acts? What kind of probleuns are dealt with by special

142 But see Sobel v. Adams, 208 F. Supp. 316 (S.D. Fla. 1962).

143 Ibid.

144 Dade County, with 933,000 voters, elected three representatives while tiny Gilchrist County, with 2,868 voters, elected one. The five most populous counties elected approximately one representative for each 106,000 voters while the five least populous counties elected one representative for each 3,226 voters. 
acts? Surely other alternatives, such as combining counties, would result in a lesser impact upon voters' interests.

The court noted that a strict population approach would result in a body too large and unwieldly and would give five counties a majority in the legislature. This is dependent upon the ratio or formula used, however, and is not an inevitable result. Furthermore, unlike the approach taken on remand in Baker where the two-thirds formula in one house was not considered included in a "population standard," the court held that population need not be a factor in the Florida Senate since population was "heavily weighted" in the lower house. The court felt, however, that the senate scheme must have some rational basis. Apparently, geographical representation was rational despite disparities.

Under the proposed plan, Dade County with 19 per cent of the state's population would elect one of the forty-six state senators. (It would also elect 11 per cent of the representatives.) A rational basis was found, but the inquiry was only directed at the rationality of combining counties to form senatorial districts. It was proper, the court held, to combine counties with common geograprical locations, contiguous areas, and with a general unity of economic interests.

The court further noted that some county alignments resulted from the need to create districts from neighboring counties and possibly from the political necessity of concessions to insure passage of the measure. ${ }^{146}$ This is the first judicial recognition of the political considerations involved in the passage of this kind of legislation. The court did not attempt to limit this consideration to reasonableness or to measure the effect of concessions on the plan as a whole. Perhaps, even if possible, this would have been unwise.

Although minimal representation is afforded to each county, it is not clear why the remaining legislative seats cannot be apportioned on the basis of population. The court's answer is that the legislature would be too large and unwieldly, and Dade County would have as many representatives as the 50 least populous counties. ${ }^{146}$ The court characterizes these "evils" as irrational. This characterization demonstrates the court's reluctance to apply a strict notion of political equality. The court's holding that it is irrational to give a majority of the voters a majority in the legislature because some counties will elect more representatives than others represents a high order of circular reasoning.

In any event, the court approved an amendment providing for disparities in the Florida House and even greater disparities in the senate. One representative (out of 15) from Dade County represents 62,000 voters

145 Sobel v. Adams, supra note 142 , at 323.

$146 I d$. at 322 . 
while the representative from Gilchrist represents 2,868 voters. The amendment reduces the maximum disparity from 100 to 1 to 20 to 1 . Although this reduction is an improvement, it permits disparities exceeding those declared invidious $\mathrm{m}$ other states. ${ }^{147}$

A similar approach was taken in W.M.C.A., Inc. v. Simon ${ }^{148}$ in upholding New York's minimal representation. The court stressed a historical policy of county representation. Senate districts were found proper because designed to promote accessibility of senators to their constituents. The court implied that communication between legislators and their constituents was more difficult in rural areas. This assumption is questionable in the light of modern communications and improved roads. Many believe that it is easier to make news and to campaign in rural areas than in cities. ${ }^{149}$ Implicit also in the opinion is the belief that urban voters tend to vote as a bloc more than rural voters. The court felt it "worthy of consideration" that interests of the upstate counties miglit be diverse while those of the city districts might be unified. ${ }^{150}$ This assumption is also subject to question. It is at least arguable that rural areas, with a less heterogeneous population and a closer identity of interests, have greater social pressures leading to political cohesion than do urban areas. ${ }^{151}$ Political history does does not show a solid urban vote aligned against an equally solid rural vote. Cleavages cut across all communities. ${ }^{152}$ Furthermore, even if the court's assumption were true, it is not clear how the legislature could decide to give the minority of rural interests a legislative majority.

Minimum representation has often been combined with maximum limits placed upon the number of representatives to be elected or counties which

147 In spite of the court's advisory opinion that the amendment was constitutional, the proposal was rejected. A new apportionment act was passed by the legislature in a specially convened session. Minimal representation is apparently accorded all counties in the senate except that Dade County is given two senators. The number of senators was decreased from 46 to 43 . Dade County, with $19 \%$ of the state's population, now elects $4.6 \%$ of the state's senators. The new act was upheld although the court expressed misgivings that more than one senator was given to Dade County. Sobel v. Adams, 214 F. Supp. 811 (S.D. Fla. 1963).

A far more rigorous approach has been taken by a three-judge court in Iowa. Davis v. Synhorst, 217 F. Supp. 492 (S.D. Iowa 1963). No rational basis was found for constitutional provisions which granted one representative to each county in the upper house and at least one in the lower house. Judicial relief was stayed pending the 1963 elections at which the constitutional amendments would be voted upon.

Less than $30 \%$ of Iowa's population elected a majority of the lower louse, and the disparity was as high as 18 to 1 . A majority of the senate could be elected by $35 \%$ of the population, and the disparity was 9 to 1 .

148208 F. Supp. 368 (S.D.N.Y. 1962), prob. juris. noted, 31 U.S.L. WeEK 3404 (U.S.

June 11, 1963) (No. 460).

140 Twentzeth Century Fund, ONe MaN-ONe Vote 7 (1962).

160208 F. Supp. at 379.

161 Emerson, Malapportionment and Judicial Power, 72 YALE L.J. 64, 73 (1962).

152 Schattschneider, Urbanization and Reapportionment, 72 YAre L.J. 7, 8 (1962). 
can be combined into legislative districts. ${ }^{153}$ This device either limits the total number of seats in a legislature or the number of representatives which may be elected from any district. ${ }^{154}$

Another device, used to maximize minority control, conditions extra representatives on the existence of a large population. Colorado, for example, permits one representative to be elected for the first 19,000 people in a county and one representative for each additional $50,000 .{ }^{155}$ One senator may be elected from a district with 8,000 persons while a second senator requires an additional 25,000 persons. Thus, a county with 32,000 persons elects one senator while four counties each with populations of 8,000 elect a total of four senators.

In Idaho 15.2 per cent of the population elects 35 per cent of the representatives in the lower house and 50 per cent of the senators. The assembly is controlled by 32.7 per cent of the population. Clark and Camas counties with 915 and 917 residents, respectively, elect one representative as does Elmore and Cassia counties with 16,719 and 16,121 residents, respectively. The state constitution requires one senator and one representative to be elected per county and limits the number of representatives to three times the number of senators. Besides the initial representatives, the constitution permits an extra representative for counties with a population of 17,000 or more. The system has been recently upheld ${ }^{150}$ on the dubious ground that disparities originated only from the state constitution. The court did not seem to recognize that a federal standard was involved.

The Idaho scheme may represent a numbers game not wholly novel in the area of state and municipal law..$^{157}$ The number of residents required to elect a second representative has risen from 2,500 in $1921,10,000$ in

153 Jackman v. Bodine, 31 U.S.L. WeEk 2472 (N.J. Super. Ct. Mar. 1, 1963). The court upheld a constitutional requirement limiting total membership of the lower house while guaranteeing each county one representative. Minimal representation in the senate was also upheld although the constitution permits $19 \%$ of the state's population to control the upper house. State constitutions often prohibit the combination of more than a specified number of countics into legislative districts. A Kentucky court has held that this requirement can be ignored when necessary to "effectuate reasonable equality of representation ..." which is also required by the state constitution. Combs v. Mathews, 31 U.S.L. WEEK 2396 (Ky. Ct. App. Jan. 31, 1963).

154 Moss v. Burkhart, supra note 106.

155 Coso. Const. art. V, § 63-1-2.

150 Caesar v. Williams, 371 P.2d 241 (Idaho 1962).

157 The constitutions of many states limit state power over local affairs in a number of ways. Constitutional provisions often require laws to be umiform in nature throughout the state or prohibit special or local legislation. Classifications can be inade but they must be based on a reasonable difference in situation and must be related to a proper state purpose. Classification based on substantial population differences are common and are usually upheld if open ended. Nevertheless, legislatures commonly abuse classification schemes by raising population minimums when certain areas approach the required population. See RHYNE, MUNICIPAL LAW 65-66 (1957); FordHAM, LOCAL GOVERNMENT LAW 60-72 (1949). 
$1933,12,555$ in 1941 , to 17,000 in 1951. Elmore and Cassia counties have slightly under 17,000 residents at present.

Fimally, an analogy to the United States Senate is also inappropriate to justify gross disparities in upper houses. The states were considered "sovereign" bodies at the time of the formation of the union, and the present makeup of the federal legislative branch was the result of compromise. Counties, on the other hand, are legislative conveniences. That statutes affect counties as units does not alone seem sufficient to justify disparities. Other facts are relevant, such as the proportion of special acts to the total number of acts passed. To what areas or problems are the special acts directed? The urban areas certainly have as many pressing needs as rural areas. That many special acts affect urban areas only emphasizes the need for equitable representation. If, on the other hand, the special acts affect rural areas predominantly, it may only demonstrate that these areas control the legislature.

Closely related to the problem of minimal representation is the frank protection of rural minorities. Most writers consider Baker in an urbanrural context. ${ }^{158}$ Although urban areas are usually the major targets of malapportionment, the statement that rural interests are the only minority interests protected is too broad. The "rural" designation is probably a label covering a variety of other interests, including political units, regional interests, sparsely settled areas, or industrial interests.

Assuming the rural-urban conflict is the main battleground, however, what amount of protection should be afforded the rural interests? Granting that a farm minority should have a vote in the state legislature, it does not follow that they must elect the majority of representatives, even in one house. No one contends that urban minorities im North Dakota should be given disproportionate power. The very fact that district lines are drawn means that local interests are represented to some extent. It is unclear why rural interests should be chosen for special favor over other groups, nor is it clear how any minority group can be favored in this way.

The rural problem is probably historical and not the result of reasoned legislative choice. In the mineteenth century the bulk of the population lived in rural areas. Slight discrepancies were often defended on the ground that farmers represented traditional moral virtues while the city dwellers were steeped in vice and radicalism. City dwellers of the same political hue as the farmers would often vote to block reapportionnient. By the twentieth century, however, the probem became basically one of a minority clinging to disproportionate power. ${ }^{159}$ Thus, the problem stems not so much from a desire to protect minorities, but froni the fact that rural areas once

158 See, e.g., Schattschneider, supra note 152.

159 See LaRson, REAPportionMent and tHe Courts 5-1I (1962). 
contained a majority of the population and still possess majority power even though the centers of population have radically shifted.

The argument against variation from a population standard necessarily denies the propriety of any other consideration..$^{100}$ Equality, the argument continues, is more than just a precise mathematical formula but involves fundamental principles of representative government. When an "area" is given as many representatives as a more populous area, it simply means that the voters in the sparse areas have more representation. Granted that rural interests may have special needs, urban areas have problems at least as great. Moreover, regional interests can be recoguized when district lines are drawn.

State politics is more complex than the urban-rural discussion indicates, however, and geographical divisions exist in many states. In the eighteenth century, the struggle for fair representation was geographical in nature and malapportionment favored the cities. The seaboard areas of the middleAtlantic states were overrepresented in the state assemblies in relation to the western frontiersmen ${ }^{101}$ Charges were made that the east did not understand the needs of the west.

Geographical conflicts still exist in many states. In California, for example, a north-south rivalry has existed for many years. To some extent this is a product of rivalry between California's large metropolitan areas, Los Angeles and San Francisco. The conflict, however, has other aspects. One critical issue in California politics is water; the north has water and the south needs more. Thus, although the south contains a majority of the population, the north is unwilling to permit the south to gain control. Recently, rural and urban groups in the north campaigned vigorously against a proposed apportionment amendment even though San Francisco also would have gained senate seats. ${ }^{\mathbf{1 6 2}}$

Geographical struggles are also an aspect of population location. Thus, apportionment problems in New York and Michigan are primarily caused by the presence of a single, heavily populated area in the state.

160 Twenteth Century Fund, ONe MaN-ONe Vote (1962). The "only legitimate basis of representation in a state legislature is people." Id. at 3.

161 LARSON, op. cit. supra note 159 , at 9-10.

162 Each county may elect no more than one senator, but small counties are grouped into districts of no more than three counties each. Reapportionment is himited to minor shifts which involve only a few of the less populous counties. See Baker, State Constitutions: ReaprorTIONMENT 64 (1960).

Thus, while Los Angeles County with 6,500,000 residents is represented by only one of the 40 state senators, districts with as few as 14,294 voters also elect one senator. As a result, $10.7 \%$ of the voters are able to control the state senate.

The mayor of Los Angeles has begun legal proceedings to challenge the senate's apportionment. Yorty v. Anderson, (Sac. 7455) petition for writ of mandate filed in Cahifornia Supreme Court, December 28, 1962. 
Although small counties fear losing control to more populous urban areas, the large urban areas with fairly static populations also fear a loss of representation to newer, expanding urban areas. ${ }^{163}$ This new dimension to the problem is illustrated by New Jersey. Because the lower house is limited to sixty members, with each county receiving at least one vote, a redistribution of seats to accord fuller representation to the new, expanding areas would decrease the representation of the larger as well as the smaller areas. Thus, a redistribution of seats after the 1950 census was blocked by the larger counties. ${ }^{164}$

In addition to the minimum representation and minority protection arguments, a state may assert that area representation, especially in one house, is necessary to mamtam a system of checks and balances. ${ }^{165}$ Thus, the upper house restrains the lower house from enacting popular but dubious legislation. It may be generally true that sparsely settled areas send conservatives to the legislature, but it is doubtful that the bounds of conservatism and wisdom are always coterminous. The real value of a check should not be determined by the extent to which each house can frustrate the other but rather by the wisdom of the check exerted. ${ }^{166}$

It is doubtful that area representation is required for checks and balances. Many states provide a population basis for both houses. Moreover, the purpose of bicameralism is not necessarily to contrast different bases of representation. Popularly based houses probably would not mirror each other, for each legislator represents a different combination of voters. The upper house is usually smaller than the lower house so the senators represent larger districts. There would be differences in legislators' terms of office, as well as in political views. Intra-party alignments would also aid in creating houses of different composition.

Opposite approaches to this problem have been taken by courts in Maryland ${ }^{167}$ and Virginia. ${ }^{168} \mathrm{~A}$ federal court in Virginia gave the legisla-

163 LARSON, op. cit. supra note 159, at 63.

104 See Asbury Park Press, Inc. v. Wooley, 33 N.J. 1, 161 A.2d 705 (1960). The disparity in the lower house is 18 to 1 and $46 \%$ of the voters can elect a majority of representatives.

165 An attempt is usually made to parallel the Federal system; hence the plan is called a "Federal" plan.

"What is rational for the federal government ought not to be condemned as irrational and invidious for Ohio." Nolan v. Rhodes, 31 U.S. L. WEEK 2641 (S.D. Ohio June 25, 1963). The court upheld the minimal representation given to each Ohio county in the lower house irrespective of population. Orro Const. art XI. Since the senate is based upon population, the court upheld minimal representation in the lower house because otherwise "there does not seem to be inuch reason for a bicameral legislature." 31 U.S. L. WeEK at 2641.

166 Hagan, The Bicameral Principle in State Legislatures, 11 J. PuB. L. 310 (1962).

167 Maryland Comm. for Fair Representation v. Tawes, 229 Md. 445, 184 A.2d 710 (1962), prob. juris. noted, 31 U.S.L. WeEK 3404 (U.S. June 11, 1963) (No. 554).

168 Mann v. Davis, 213 F. Supp. 577 (E.D. Va. 1962), prob. juris. noted, 31 U.S.L. WEEK 3404 (U.S. June 11, 1963) (No. 797). 
ture two months to revamp both houses on the basis of substantial equal representation. ${ }^{160}$ The court rejected an analogy to the Federal system as unsound because state subdivisions, unlike states in the unions, possessed no "autonomy." The court felt that the only reason for bicameralism today is to provide checks and balances; it rejected the notion that bicameral legislatures were designed to contrast different bases of apportionment.

Virgima has apportioned every ten years and is considered one of the most representative states. Nevertheless, the court compared the largest and smallest districts and noted a 2 to 1 disparity in the state senate and a 4 to 1 disparity in the lower house. Although the court refused to express an "allowable tolerance of divergence," it held that the state had presented no evidence to justify the existing disparities. Population was not the "sole or definitive measure" of legislative districting. Other factors could be considered, such as, compactness, contignity of territory, community of interest, and natural and historical lines. The rigor of the court's approach is certainly in contrast with the more lenient approaches taken in cases of greater disparities.

Voters in Maryland, representing four suburban counties and the City of Baltimore, unsuccessfully attacked Maryland's apportionment scheme. ${ }^{170}$ The ten districts represented by the plaintiffs contain 76 per cent of the state's population but elect only 34 per cent of the senators and 49 per cent of the representatives. The state supreme court originally remanded the case for further hearings to the circuit court which had sustamed defendants' demurrer. ${ }^{171}$ The legislature altered the scheme by adding nineteen representatives to the lower house so that the ten districts were represented by 55 per cent of the representatives. The plan was then accepted by the state supreme court.

The court held that the system protected minorities, prevented hasty but popular legislation, and preserved the system of checks and balances. A "federal analogy" was employed to justify the disparities found in the upper house. This analogy is inappropriate. States are unitary in organization, and counties are mere administrative subdivisions. The Federal government, on the other hand, is composed of sovereign states whose residual sovereignty was protected under the Constitution by equal representation in the United States Senate. The arrangement was created by compromise and has no relation to the situation existing in any state.

Some courts apparently have adopted a disguised "federal plan" in which the use of non-population factors for the state's upper house is given

169 The judgment declared the apportionment laws invalid but stayed an injunction until January 31, 1963, to permit legislative action.

170 Maryland Comm. for Fair Representation v. Tawes, supra note $16 \%$.

171 Maryland Comm. for Fair Representation v. Tawes, 228 Md. 412, 180 A.2d 656 (1962). 
greater deference than in the lower house. Thus, disparities in the upper house would be permissible if the lower house was based solely ${ }^{172}$ or substantially ${ }^{173}$ on population. The use of different bases of apportionment in the two houses, however, cannot be justified by using the federal system as a historical precedent. The rejection of this analogy, however, does not necessarily compel acceptance of a political equality standard. Circumstances existing in a state may justify a system which gives some weight to non-population factors, such as historical recognition of subdivisions of the state in one house. This approach would not necessarily result in the preservation of past evils since a rational basis would still be required for the plan adopted. ${ }^{174}$ Great deference to non-population factors will probably not be accorded, however, for it would be no help to eject a minority from control of one house only to guarantee their control of the other house.

\section{CONCLUSION}

Conclusions are risky at this stage of development, but some observations can be made. Courts are beginning their analysis with an assumption of voter equality. This becomes a standard which may be varied only by putting forth over-balancing state interests. The state apportionment scheme will have to be rationally organized. The Constitution will set outer limits on state variations from voter equality. Malapportionment occurs at some point as the state scheme departs from a 1 to 1 ratio of representation of all voters. It is not clear, however, when this critical point is reached. This point will probably not be mathematically determined except as state considerations warrant such specificity. A case by case approach is proper because local considerations will be relevant to the rationatity of the state's arrangement.

172 Baker v. Carr, 206 F. Supp. 341 (M.D. Tenn. 1962). A district court in Delaware has has employed the Gray standard to invalidate that state's apportionment provisions as they existed both prior to and after amendment in 1963. Sincock v. Duffy, 215 F. Supp. 169 (D. Del. 1963). The old and new constitutional sections were adjudicated in order to avoid the "intricacies of law related to survival or revival of constitutional provisions." Id. at 172 . Under the pre-1963 provisions, $18 \%$ of the population could elect a majority of the lower house and $22 \%$ could control the senate. The 1963 amendment permitted $28 \%$ of the population to elect a majority to the lower house and $31 \%$ to elect a majority to the senate.

The court held that one house must be based on an equal population basis as consistent with rationality as possible. Thus, the result is similar to the approach taken by other postBaker courts. Although verbally accepting the Gray standard for both louses and rejecting a Federal analogy, the court held that area factors could be considered in the senate as long as there is no disparity anong districts within each county. $I d$, at 190. Why uniformity among districts in different counties is not required is unexplained. Furthermore, the court did not explain why non-population factors can appropriately be considered in one house.

173 Toombs v. Fortson, supre note 138; Moss v. Burkhart, 207 F. Supp. 885 (W.D. Okla. 1962).

174 Baker v. Carr, supra note 172. 
Difficult problems remain after political equality is designated as the starting point of analysis and the factors to be considered are determined. A particularistic analysis will be difficult to strike unless the Court devises primciples to determine when inequality exceeds the state's asserted justifications. ${ }^{175}$

Gerrymandering, the other side of the malapportionment problem, can perform much the same function as unequal districts. Whether the Court will broaden the scope of the fourteenth amendment to include contiguity and compactness and to require neutral districting rules remains to be seen. It would require highly precise judcial tools to review the rationality of districting, and the Court may well find that this is a thicket too thorny to enter.

Thus far, Baker v. Carr has not precipitated the adverse reaction many somberly predicted. Perhaps the decision has "activated a latent consensus in American opinion."176 Although perfect voter equality may not be a part of our political heritage, traditional principles require that rule must be by the consent of the governed. Few Americans would suggest that their votes could legally be diluted in favor of others. The extent of this consensus, however, has yet to be explored. ${ }^{177}$

175 This problem is inherent in the use of a balancing formula. See Fried, Two Concepts of Interests: Some Reflections on the Supreme Court's Balancing Test, 76 HARv. L. REv. 755, 775 (1963).

176 McCloskey, Foreword: The Reapportionment Case, 76 HARv. L. REv. 54, 59 (1962).

177 There are signs indicating that an organized revolt is in progress. The Council of State Governments proposed three constitutional amendments in December 1962. The first proposal provides that the Constitution "shall not limit any state in the apportionment of representation in its legislature." The second proposal would permit the states to amend the Constitution without obtaining the approval of Congress or of a constitutional convention. The third proposal would create a "Court of the Union," composed of the chief justices of the 50 states, to review Supreme Court decisions relating to federal-state relations.

With an astonishing lack of discussion or debate, twelve legislatures lad, as of May 1963, approved the apportionment amendment, eleven the proposal for bypassing Congress in the amendment procedure, and three the "Court of the Union." N.Y. Times, May 22, 1963, p. 23, col. 2. 